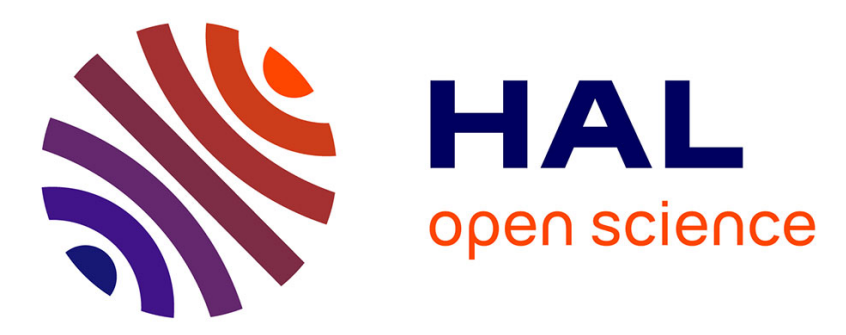

\title{
A pressure cell for inelastic neutron scattering up to 35 kbar
}

\author{
U. Walter
}

\section{To cite this version:}

U. Walter. A pressure cell for inelastic neutron scattering up to 35 kbar. Revue de Physique Appliquée, 1984, 19 (9), pp.833-836. 10.1051/rphysap:01984001909083300 . jpa-00245273

\section{HAL Id: jpa-00245273 https://hal.science/jpa-00245273}

Submitted on 1 Jan 1984

HAL is a multi-disciplinary open access archive for the deposit and dissemination of scientific research documents, whether they are published or not. The documents may come from teaching and research institutions in France or abroad, or from public or private research centers.
L'archive ouverte pluridisciplinaire HAL, est destinée au dépôt et à la diffusion de documents scientifiques de niveau recherche, publiés ou non, émanant des établissements d'enseignement et de recherche français ou étrangers, des laboratoires publics ou privés. 


\title{
A pressure cell for inelastic neutron scattering up to $35 \mathrm{kbar}$
}

\author{
U. Walter \\ II. Physikalisches Institut, Universität zu Köln, Zülpicherstraße 77, D-5000 Köln 41, F.R.G.
}

\begin{abstract}
Résumé. - Une cellule à pression basée sur la cellule de McWhan (Bell Labs) et la cellule de Bloch (ILL) sont présentées. Elle tient compte des exigences spéciales à la diffusion inélastique des neutrons. L'accent est mis sur des investigations empiriques et théoriques pour trouver la géométrie optimum d'une cellule à piston et cylindre supporté. Des spectres de temps de vol préliminaires illustrent les résultats et problèmes de quelques expériences de diffusion inélastique de neutrons avec une telle cellule à pression.
\end{abstract}

\begin{abstract}
A pressure cell based on the McWhan cell (Bell Labs) and the Bloch cell (ILL) will be presented. It takes into account the special requirements of inelastic neutron scattering. Stress will be laid on empirical and theoretical investigations on how to find the optimum geometry of a supported piston cylinder cell. Preliminary time of flight spectra will demonstrate the results and problems of some inelastic neutron experiments with such a pressure cell.
\end{abstract}

It is obviously clear that a high pressure cell for neutron scattering must be a compromise between highest attainable pressure $P_{\max }$ and largest sample volume $V_{\max }$. This is due to the limited energy product $P_{\max } \cdot V_{\max }$, which can be supported by the surrounding pressure cylinder. This 'compromise must be worked out for each individual pressure cell. In the last decade many different materials and geometries have been considered and tested [1]. For pressures greater than $14 \mathrm{kbar}$ the only successful type of pressure cell turns out to be the supported piston cylinder with $\mathrm{Al}_{2} \mathrm{O}_{3}$ (LUCALOX, WIDALOX) pressure cylinders (Fig. 1). The highly complicated geometry of this type of cell excludes standard theoretical investigations, so that the only procedure to obtain results is the trial and error method.

One of the aims of this work was to extract rules of design from the pressure cells constructed up to now and to compare them with the outcome of finite element calculations in order to understand the interrelations of the main parameters. In an accompanying step a portable pressure cell was built, based on two successful cells $[2,3]$ with a pressure range up to $35 \mathrm{kbar}$. The dimensions of this pressure cell were chosen to fit into cryostats at the ILL and the KFA Jülich. Furthermore this cell was designed for quasielastic and inelastic neutron scattering, i.e. for a minimum background over the whole range of energy transfer.

Figure 1a shows the completed cell and figure $1 \mathrm{~b}$

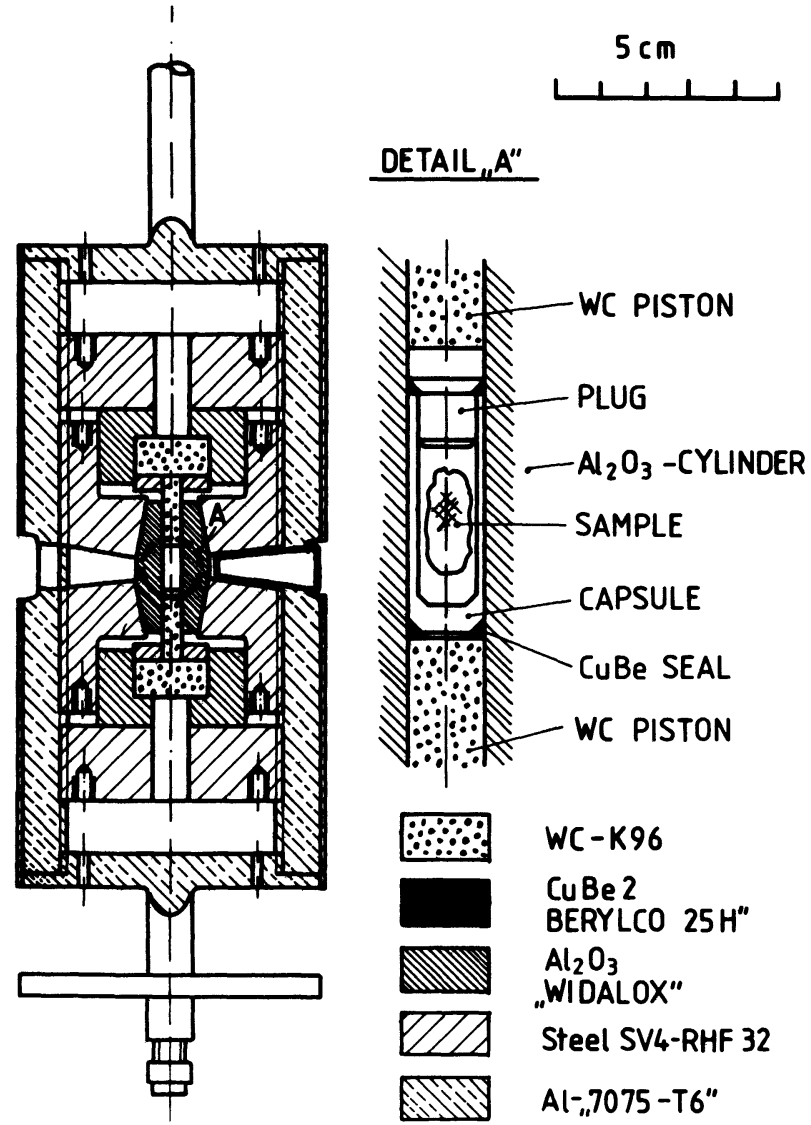

Fig. 1a. - Supported piston cylinder cell with minimum background scattering. 


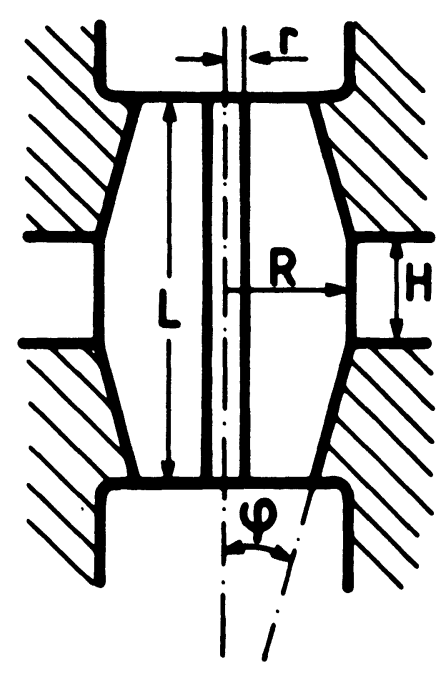

Fig. 1b. - Characteristic inner shape of a supported piston cylinder cell.

exhibits the central part of the supported piston cylinder to be discussed in the following and defines its characteristic dimensions. From these dimensions we define the following parameters

$$
\begin{aligned}
K & =R / r \\
\Delta \phi & =2(R-r) \\
D & =\mu(\lambda) \cdot R
\end{aligned}
$$

where $\mu(\lambda)$ is the linear absorption coefficient of the pressure cylinder $\left[\mu(\lambda=1.08 \AA)=0.11 \mathrm{~cm}^{-1}\right.$ for WIDALOX $R$ ]. Theory [4] tells us that the highest attainable pressure $P_{\max }$ of a thick cylinder is

$$
P_{\max } \propto \ln (K)
$$

For the partly supported cylinder like in figure 1 we expect more or less the same dependency, however, with an additional dependence on the characteristic ratio of the unsupported area $H / \Delta \phi$. Indeed if one plots the values $P_{\max } / \ln K$ versus $H / \Delta \phi$ for all the supported neutron pressure cells known up to now (Fig. 2) one finds a roughly linear relationship. With this relation in mind one is able to maximize the signal $I$

$$
\begin{aligned}
I & =I(K, H, D, R)=(\text { sample volume }) \times(\text { absorption }) \\
& =I\left(K, P_{\max }, D, R\right) \quad(\text { see Fig. 2) }
\end{aligned}
$$

of the sample enclosed in the cylinder. In this equation $P_{\max }, R$ and $D$ are fixed values, which characterize the pressure cell to be designed. $R$ describes the size of the cell, whereas $P_{\max }$ defines the maximum working pressure. $K$ is the variable to be optimized.

The results are shown in figure 3 and figure 4 . Figure 3 assigns the optimum value $K$ to the given value $P_{\max }$ and to the optimal value of $H / 2 R$ $\left(\left[P_{\max }, R, D\right] \rightarrow K \rightarrow \frac{H}{2 R}\right)$. Figure 4 demonstrates

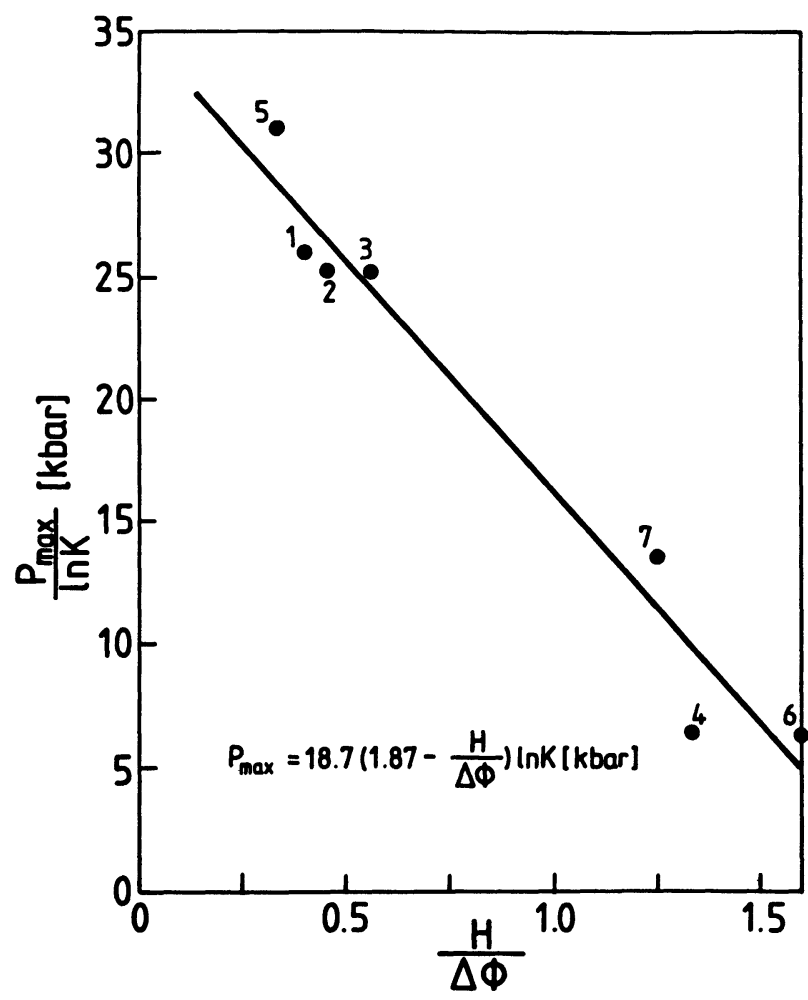

Fig. 2. - Explanation see text, 1 : Bloch cell [3], 2 : Paureau cell [5], $3:$ McWhan cell [2], 4-7 : Bloch and Paureau in : High pressure chemistry, Proc. NATO Adv. Study Inst., Corfu 1977.

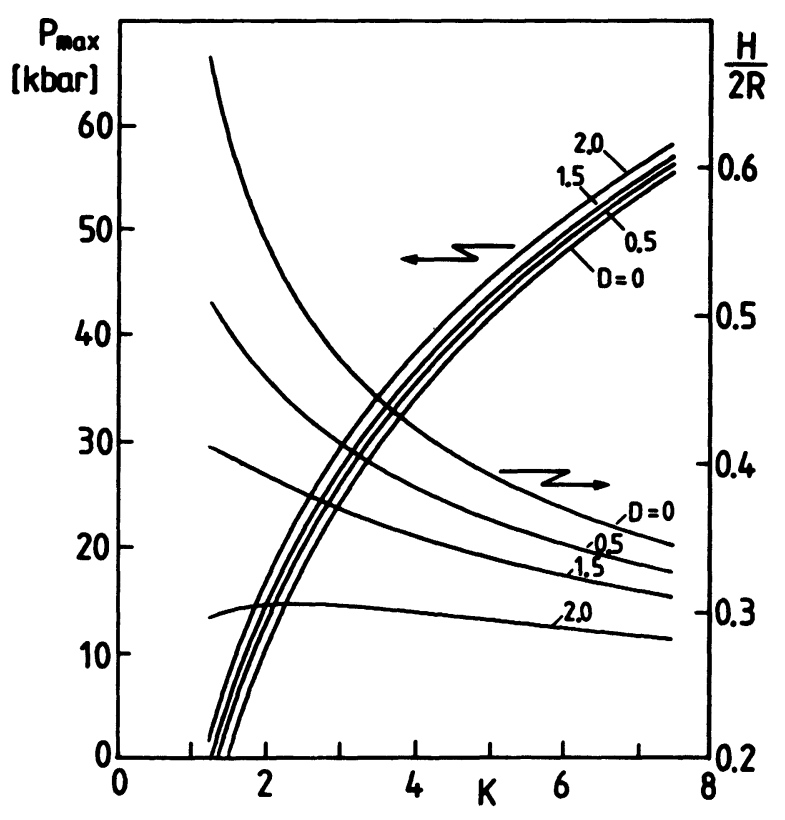

Fig. 3. - Design rules for supported piston cylinder.

how the corresponding and normalized sample signal $I / R^{3}$ depends on $K$.

Since a different neutron wavelength may change the absorption in the cylinder walls, the optimum values $K$ and thus $H / 2 R$ depends on the absorption parameter D. 


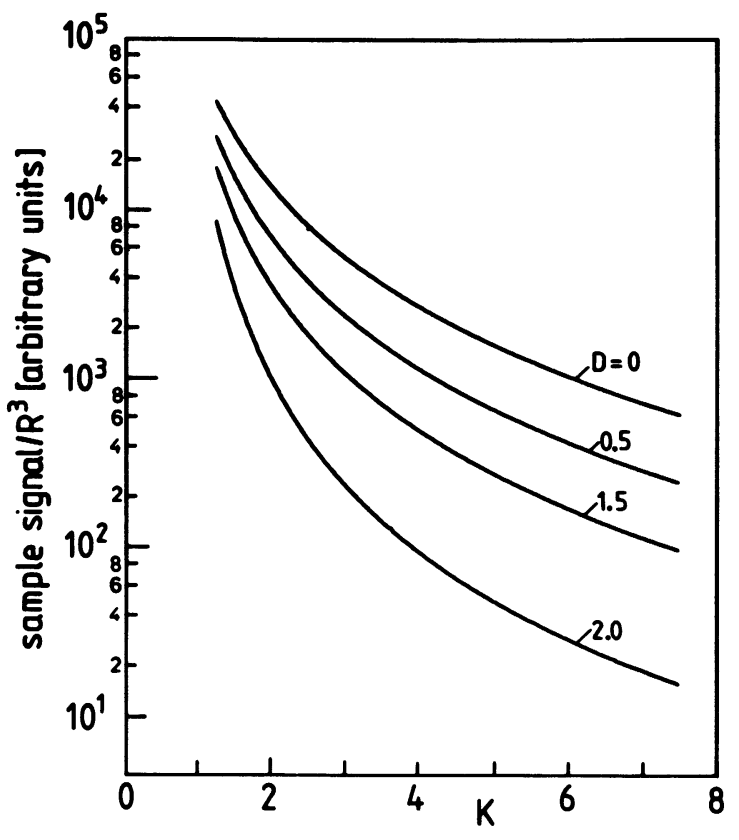

Fig. 4. - Normalized sample signal in dependence of the ratio $K$ of pressure cylinder radii.

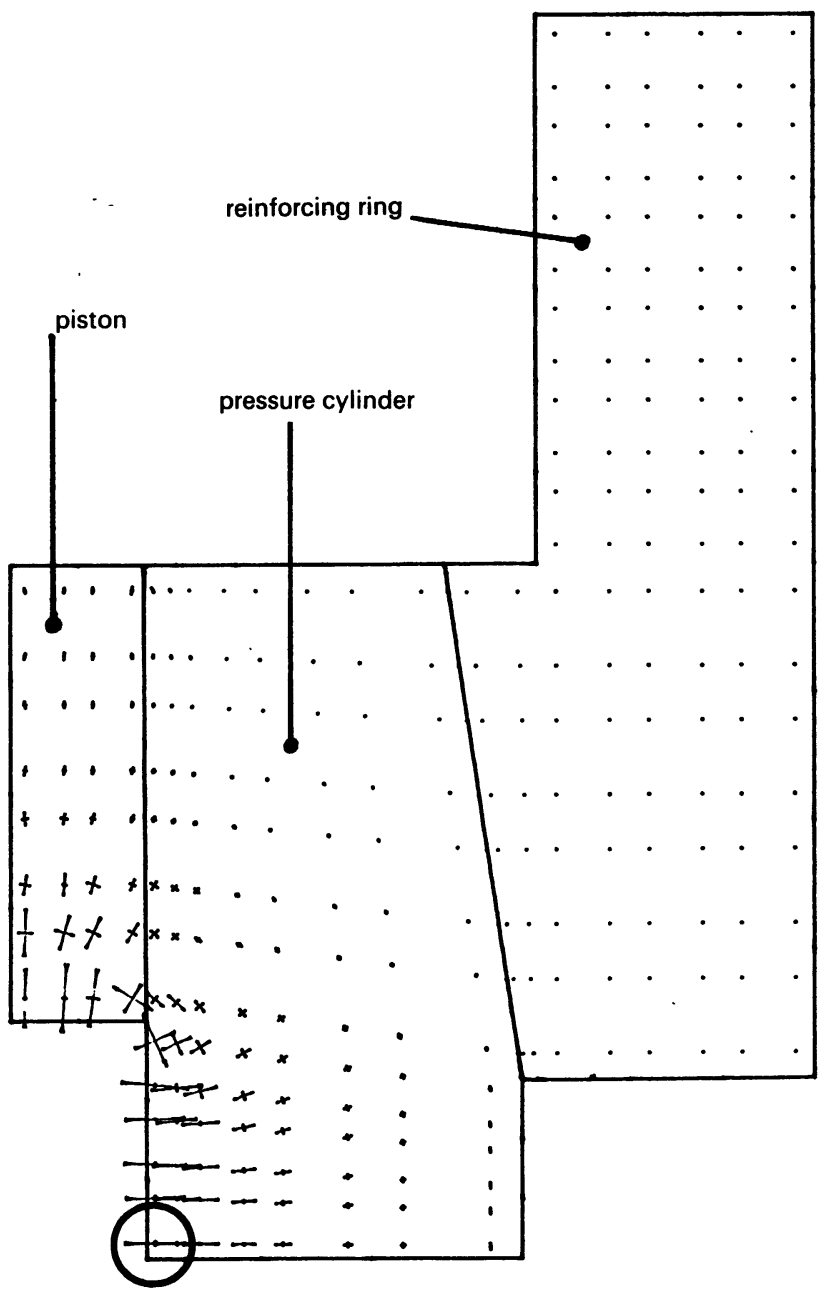

Fig. 5a. - Principal stress distribution for piston press only. Main stressed point encircled.
Notice that a choice of an excessive $P_{\max }$ may reduce the sample signal drastically. In other words, only a balanced choice of $P_{\max }$ leads to an acceptable sample signal. At this point it should be noted that a further increase in sample signal might be achieved if $D$ is taken to be variable. In this case the optimum value is found to be $D=\frac{3}{2} K /(K-1)$.

In order to answer the question what kind of cracks limit $P_{\max }$, we also did finite element calculations on different dimensions outlined in figure 1 [6]. Figure 5 shows the typical result for one of these calculations. In the case of figure 5a pressure is applied only through the pistons whereas in figure $5 \mathrm{~b}$ pressure is applied only via the external reinforcing rings (frettage force). The encircled points show the most stressed points in the reinforcing rings and the pressure cylinder, respectively. Figure $5 \mathrm{c}$ gives the locations of the beginning cracks in the pressure cylinders and how they spread out in the case when the balanced forces applied via the piston and the reinforcing rings simultaneously, lead to a maximum $P_{\max }$. In practice, cracks of type A usually lead to a destruction of the cell. However, cracks of type B have also been observed.

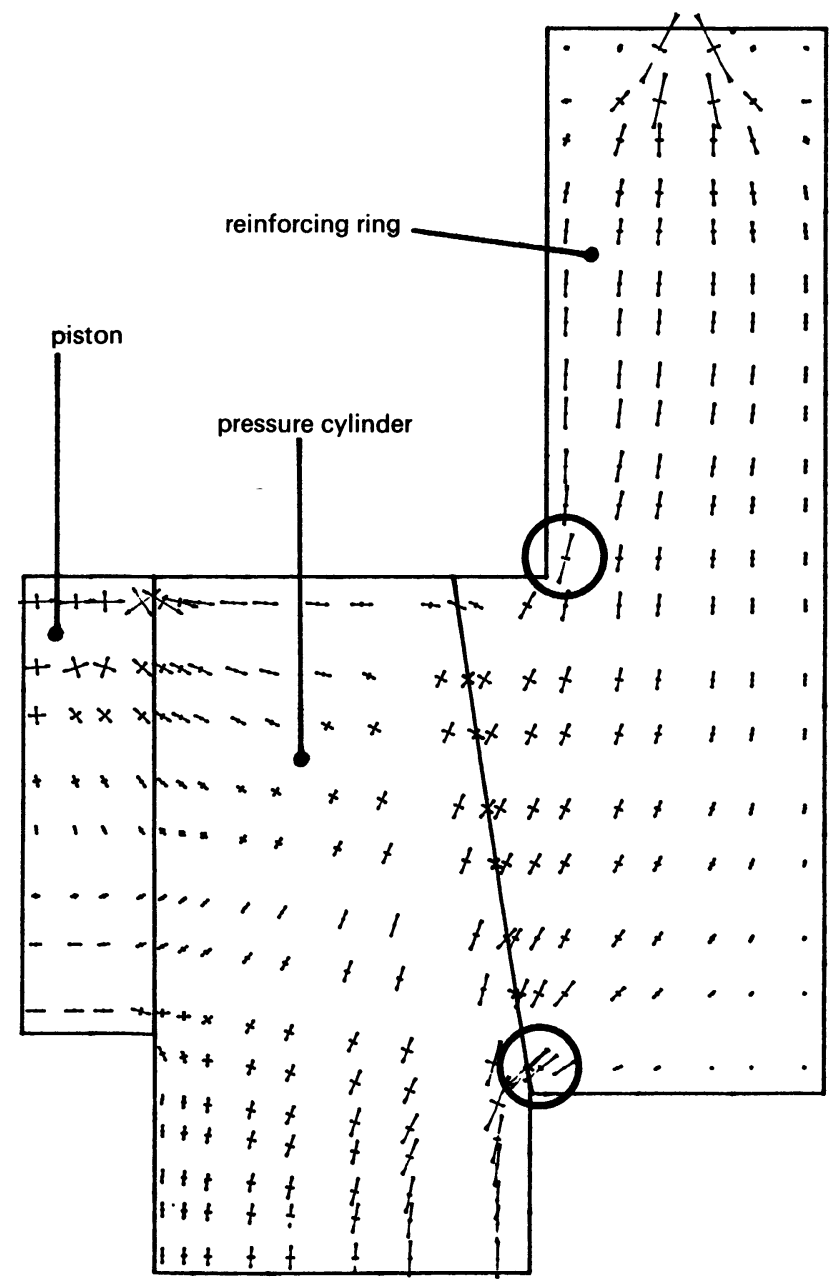

Fig. 5b. - Principal stress distribution for frettage force via reinforcing ring only. Main stressed points encircled. 


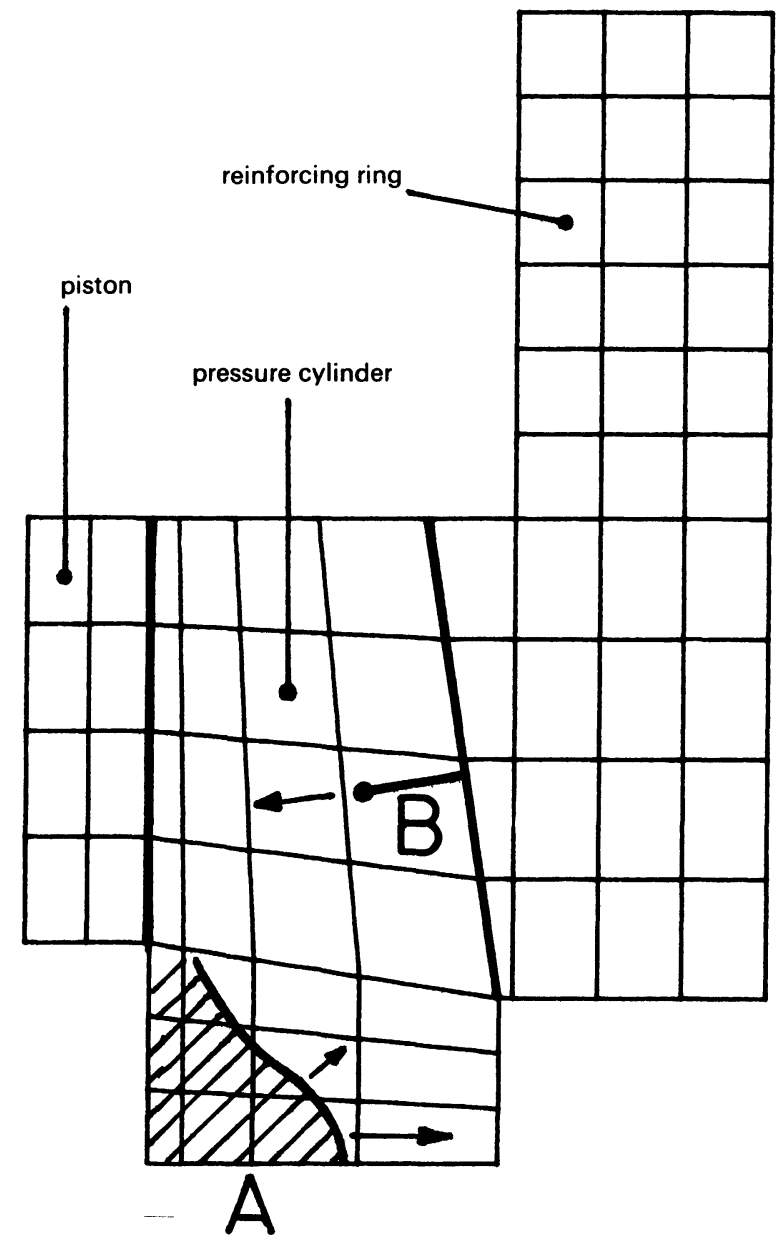

Fig. 5c. - Spreading of cracks in supported pressure cylinder. Forces applied via piston and reinforcing ring.

In figure 6 we show a time-of-flight spectrum of the cell described above, which was constructed for minimum background (open circles). The lines at about $53 \mathrm{meV}$ and $24 \mathrm{meV}$ correspond to phonons of the $\mathrm{Al}_{2} \mathrm{O}_{3}$-cylinder. As an additional information the spectrum of the pressure fluid Flourinert at zero pressure is included (full line). The strong contributions arising from that scattering can be decomposed into a broad line due to the recoil scattering (dotted line $\Gamma_{\mathrm{HWHM}}=2.2 \mathrm{meV}$ ) and a small quasielastic line due to the diffusion of the liquid molecules

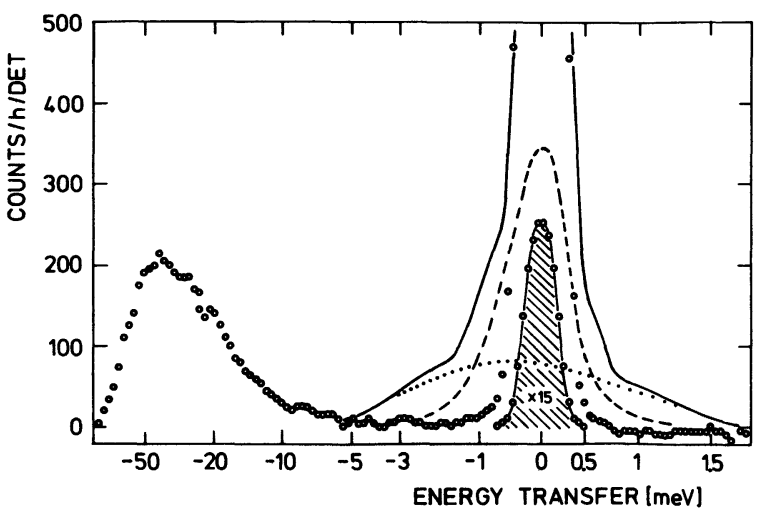

Fig. 6. - Time-of-flight spectrum of the empty pressure cell of figure 1a (open circles). Scattering function of Flourinert (full line) at zero pressure decomposed into recoil scattering (dotted line) and diffusion scattering (dashed line).

(dashed line $\Gamma_{\text {HwHM }}=0.7 \mathrm{meV}$ ). At $8 \mathrm{kbar}$ the signal of the cell with liquid is at low energy transfer identical with that of the empty pressure cell. Though the pressure of $8 \mathrm{kbar}$ is well below the solidification point of Flourinert, which is about $20 \mathrm{kbar}$ [7], the recoil effect and the diffusion nearly vanishes at that pressure, which may indicate that Flourinert is no longer fully liquid even at $8 \mathrm{kbar}$.

The main features of our cell are an input channel coated with Gd-foil which admit the incoming neutron beam just onto that part of the pressure cylinder, which contains the sample (see Fig. 1) and a transparent output window. The beam thus hits only $1 / 3-1 / 4$ of the whole cylinder, which leads to a corresponding decrease of phonon scattering in the cylinder walls. Secondly the rest of the cell surface was coated with a $\mathrm{Gd}_{2} \mathrm{O}_{3}$ film in order to reduce the constant background arising from the multiple scattering inside the cell.

\section{Acknowledgments.}

The author is grateful to D. B. McWhan for detailed information of his pressure cell and to C. Vettier for advice with respect to the modified pressure cell. Special thanks are due to the ZAT/KFA Jülich, which did the finite element calculations.

\section{References}

[1] For a review see : Carlie, C. J., Salter, D. C., High Temp.-High Pressure 10 (1978) 1.

[2] McWhan, D. B., Vettier, C., Youngblood, R., Shirane, G., Phys. Rev. B 20 (1979) 4612.

[3] Bloch, D., Paureau, J., Voison, J., Parisot, G., Rev. Sci. Instrum. 47 (1976) 296.

[4] Tsikuls (Ciklis), D. S., Handbook of Techniques in High-Pressure Research and Engineering (Plenum Press, New York) 1968.
[5] Paureau, J., Vettier, C., High Temp.-High Pressure $7,529$.

[6] For the case of non-frettaged pressure cells see also the calculations of : Kalies, J., Alt, H., High Temp.High Pressures 13 (1981) 329.

[7] McWhan, D. B., Vettier, C., J. Physique Colloq. 40 (1979) C5-107. 